\title{
Evaluation of PGAA data for provenance of lithic artifacts
}

\section{Otis CRANDELL}

Department of Geology, "Babeş-Bolyai” University, Kogălniceanu 1, 400084 Cluj-Napoca, Romania

Received October 2011; accepted December 2011

Available online 6 January 2012

DOI: $10.5038 / 1937-8602.57 .1 .1$

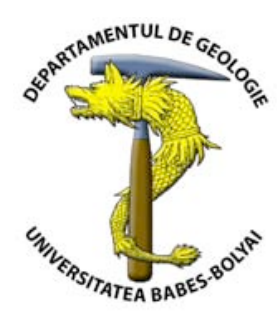

Abstract. The objectives of the study were to determine whether Prompt Gamma Activation Analyses (PGAA) could be successfully used to trace the source(s) of various Neolithic artifacts made of microcrystaline quartz. Two macroscopically identical sources of jasper from central and western Romania were analyzed by PGAA along with five Neolithic artifacts from the Limba site (Alba County). Due to the limited number of trace elements, which can be measured by PGAA, this method when used alone might produce inconclusive results for discriminating between jaspers from different sources. The interpretation of the data may be used for general assessments of provenance involving larger sample sets or in combination with optical microscopy.

Key words: PGAA, geochemistry, microcrystalline quartz, lithic artifacts, provenance, Romania, Neolithic.

\section{OVERVIEW}

Studies of provenance are valuable to archaeologists and historians because they lead to a better understanding of the existence and development of trade routes and procurement patterns in the past. The most commonly found material, which could be used to determine Stone Age trade routes, is microcrystalline quartz (MCQ). A large problem in sourcing MCQ artifacts such as chert (flint), jasper, and chalcedony, is that macroscopically they may look very similar, even if they come from different sources. From a mineralogical and chemical point of view, they are almost pure $\mathrm{SiO}_{2}$ with a very heterogeneous mixture of impurities. The impurities are often unevenly spread throughout the material (Graetsch, 1994; Rossman, 1994). This causes a broad range of the proportions of the elements found in a particular geological source, which thereby may lead to a large overlap with other sources.

It is very difficult to analyze and interpret data from heterogeneous materials such as jasper and most forms of MCQ. For chemical analysis of MCQ to be useful in provenance studies, several criteria are necessary. The method must analyze the sample in bulk, as opposed to surface spot analysis. It must be non-destructive because most artifacts used in sourcing studies, those most suspected of being of long distance origin, are considered more important and thus cannot be destroyed. As well, the method of analysis must generally be very sensitive, due to the high silica quantity (Luedtke, 1978, 1979; Luedtke and Meyers, 1984).

Previous studies by various researchers seem to indicate that there is no particular set of elements that are best suited for determining provenance of lithic artifacts, in particular quartzitic ones. It is most common to determine in each study which sets of elements are best suited to distinguishing between two or more sources of raw materials. For example Luedtke (1978) found a high significance for differentiating between lithic sources in the northeastern part of the USA from the ratios of $\mathrm{Yb}, \mathrm{Fe}$, and Eu. Julig (1995) found that $\mathrm{Al}, \mathrm{Si}, \mathrm{U}, \mathrm{Dy}$, and $\mathrm{Cl}$ when plotted on a ternary diagram gave the best results for distinguishing between cherts of the Great Lake region of North America. He later found that $\mathrm{Cl}, \mathrm{Ca}, \mathrm{Na}, \mathrm{Ba}, \mathrm{K}, \mathrm{Dy}$, and $\mathrm{Sr}$ were best suited for distinguishing between sources of chert in Syria (Julig et al., 2007). Hoard et al. (1993) found that $\mathrm{As}, \mathrm{Ce}, \mathrm{Co}, \mathrm{Cr}, \mathrm{Cs}, \mathrm{Eu}, \mathrm{Fe}, \mathrm{La}, \mathrm{Nd}, \mathrm{Sb}, \mathrm{Sm}, \mathrm{U}$, $\mathrm{Yb}$, and $\mathrm{Zn}$ worked well for distinguishing cherts from western USA.

The objectives of the study were to determine whether Prompt Gamma Activation Analyses (PGAA) could be successfully used to distinguish between jasper samples originating from different known geological sources, as well as matching similar jasper artifacts to sources. PGAA was chosen because it gives composition of the bulk materials and is non-destructive. As well, PGAA is a relatively new method of elemental analysis and is still less commonly used than Instrumental Neutron Activation Analysis (INAA).

In this study, two macroscopically identical sources of jasper from central and western Romania were analyzed. Thus, the PGAA data for samples from two areas was compared with PGAA data obtained for five Neolithic artifacts from the Limba site, Alba County (Crandell, 2008). Statistical interpretation of the elemental data was used to characterize the geological sources and to predict the origins of the five artifacts.

\section{SAMPLES AND METHODS}

A total of 18 geological samples and 5 artifacts were the subject of the study. The geological samples were analyzed by means of optical microscopy in polarized light (OM) on thin sections. 


\section{Archaeological samples}

The artifacts investigated (Fig. 1) are from the Middle Neolithic settlement at Limba and were assigned to the Vinča culture, phase A (ca. 7000 years before present) (Florescu, 2007). Artifact no. 2701 is a scraper and was found inside the remnants of a house whereas artifacts no. 2573 and 2574 (flakes) were found nearby. Artifacts no. 2542 (a flake) and 2545 (a core) were discovered together in a ritual pit (C. Florescu, pers. comm.). These artifacts were chosen because the archaeologist working with the collection from Limba, based on the contexts in which these artifacts were found, considers that they had a higher cultural value at the time of the site's occupation (C. Florescu, pers. comm.).

flake

Fig. 1. Macroscopic photos and the archaeological description of the lithic artifacts used in the study. The figures at the bottom of the picture represent the artifact number. The black scale bar at the bottom center represents $1 \mathrm{~cm}$.

\section{Geological samples}

In this project, jasper artifacts and various Si-rich rock samples were used. Jasper contains a higher amount of impurities than most other MCQ varieties and would therefore have a higher probability of exhibiting regional variations and being chemically distinguishable. All of the geological samples were macroscopically similar. All were sub-translucent to opaque, red and/or yellow, often with small speckles or dendritic lines of manganese oxides (identified in petrographic thin sections of the geological samples). The geological samples came from outcrops in western Romania (Apuseni Mts. and Southern Carpathians) (Fig. 2).

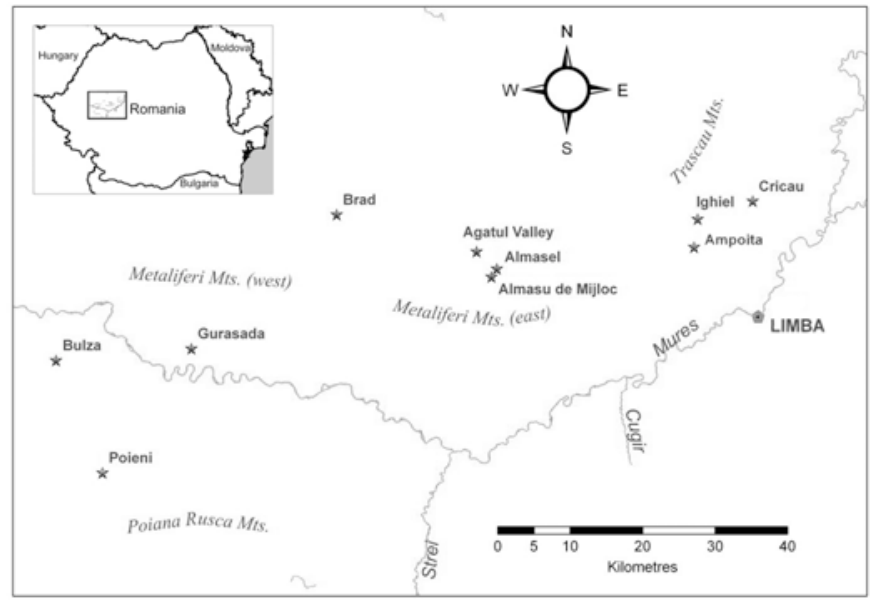

Fig. 2. The location of the geological sources used in the study. The insert in the upper-left shows the position of the map within Romania.

For this study, source zones were defined based on geography and similar geology. The zones were: a) the Western Metaliferi Mts. and b) the Eastern Metaliferi Mts. and Trascău Mts. A macroscopically similar, but petrographically different, siliceous sandstone from the Poiana Ruscă Mts. and a sinter from the Metaliferi Mts. were also analyzed for comparison. The jasper from the sources used in this study were a Studia UBB Geologia, 2012, 57 (1), 3 - 11 brownish yellow or dark red color (sometimes a mixture of both colors), opaque to sub-translucent, with medium to fine grained surfaces, dull, satiny or waxy luster, and some contained dendritic inclusions of manganese minerals. They sometimes appear brecciated, filled in with a cement of a different color or opacity. In petrographic thin sections one can see a large quantity of fine-grained quartz crystals associated with $\mathrm{Fe}$ oxi-hydroxides, i.e., goethite and hematite, which causes the yellow and red color, respectively (Fig. 3) (Table 1).
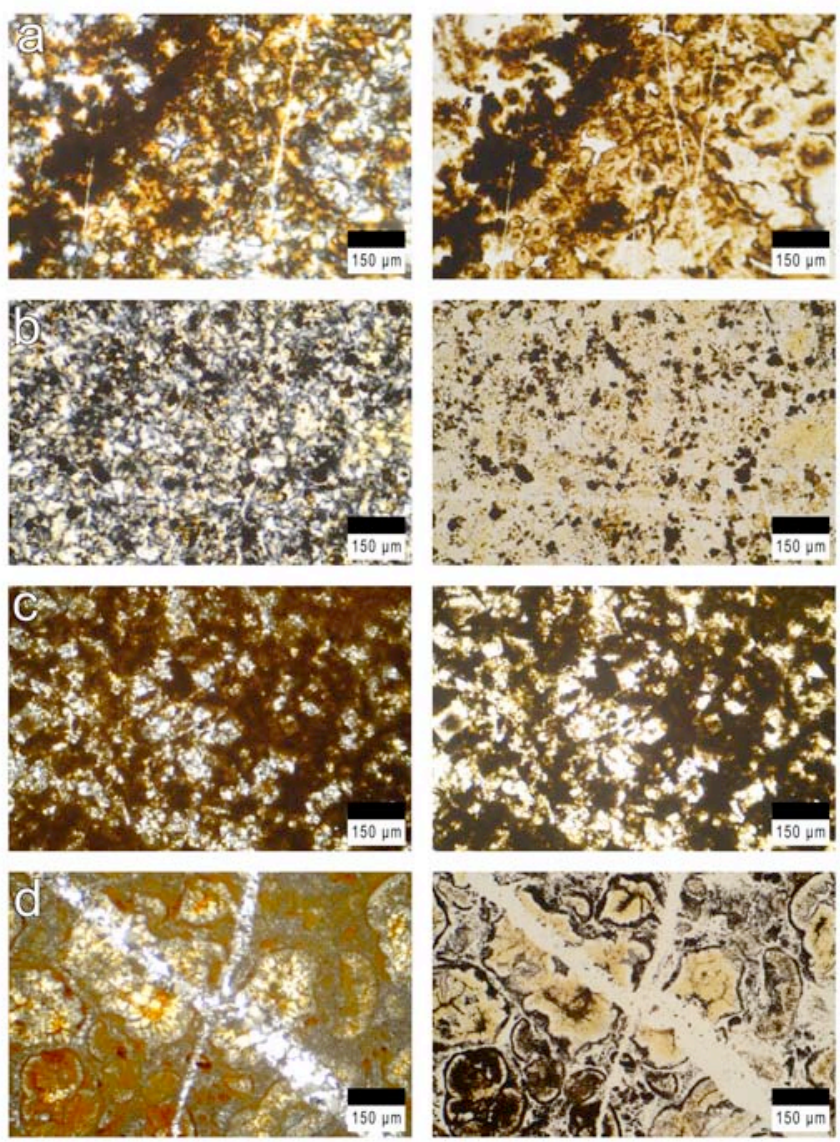

Fig. 3. Microphotographs (polarized light) of jasper samples. a) from Bulza; b) from Gurasada; c) from Almaşul de Mijloc; d) from Valea Agatului. Left side, crossed polarizer. Right side, the same with one polarizer.

The jasper samples came from outcrops located near the towns of Bulza and Gurasada (western part of the Metaliferi Mts.) and are geologically related to Miocene (Badenian-Sarmatian) pyroclastic andesite formations (Gherasi et al., 1965) ${ }^{1}$. The other samples originate from the eastern part of the Metaliferi Mts. and from the Trascău Mts. and are related to late Jurassic island arc volcanics (Ilie, 1952; Lupu et al., 1966; Russo-Săndulescu et al., 1976; Borcoş et al., 1981; Gandrabura, 1981; Lupu et al., 1986; Savu, 1990; Lupu et al., 1991; Ghiurcă, 1997a, b; Nicolae and Saccani, 2003). For this study, jasper was sampled from small veinlets in basalts, basaltic andesites, and andesites cropping out in the Agatului valley and the surroundings of Almăşel, Almaşu de Mijloc, Ampoița, Cricău, and Ighiel villages.

The Poieni quartzite samples from the Poiana Ruscă Mts. (Southern Carpathians) are of Cretaceous (Albian) age (Mureşan and Orăşanu, 1972). They present a mixture of various colors, such as light brown to whitish yellow to orange. Some samples show frequent dendritic black inclusions (Comşa, 1971, 1976).

\footnotetext{
${ }^{1}$ Chronostratigraphic units are according to the Central Paratethys time-scale (Vass and Balogh, 1987).
} 
Table 1. Comparison of microscopic and macroscopic characteristics of rock samples and artifacts.

\begin{tabular}{|c|c|c|c|c|}
\hline & Artifacts & Jasper (both groups) & Poieni quartzite & Brad sinter \\
\hline 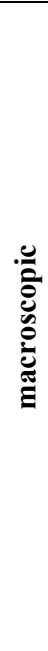 & $\begin{array}{l}\text { - waxy, dull or slightly } \\
\text { glassy luster } \\
\text { - medium grained to } \\
\text { smooth surfaces } \\
\text { - sub-translucent to } \\
\text { opaque } \\
\text { - dark red and yellow } \\
\text { - often small black } \\
\text { speckles or dendritic } \\
\text { lines } \\
\text { - some cracks in the } \\
\text { material are infilled with } \\
\text { chalcedony } \\
\text { - Surfaces show the } \\
\text { material fractures } \\
\text { conchoidally }\end{array}$ & $\begin{array}{l}\text { - waxy, satiny, slightly glassy or dull } \\
\text { luster } \\
\text { - medium grained to smooth surfaces } \\
\text { - sub-translucent to opaque } \\
\text { - dark red and/or brownish yellow } \\
\text { (sometimes a mixture of both) } \\
\text { - often small black speckles or } \\
\text { dendritic lines } \\
\text { - some samples appear brecciated or } \\
\text { have internal cracks infilled with } \\
\text { chalcedony } \\
\text { - most samples break with a perfect } \\
\text { conchoidal fracture and a relatively } \\
\text { sharp edge. Some samples have a } \\
\text { partially irregular fracture but } \\
\text { generally conchoidal }\end{array}$ & $\begin{array}{l}\text { - mainly a dull luster } \\
\text { - most samples are medium } \\
\text { grained } \\
\text { - mainly opaque } \\
\text { - colors vary from light } \\
\text { brown to whitish yellow } \\
\text { and orange. } \\
\text { - some samples have black } \\
\text { dendritic inclusions } \\
\text { - fracturing varies from } \\
\text { perfectly conchoidal to } \\
\text { irregular }\end{array}$ & $\begin{array}{l}\text { - glassy luster } \\
\text { - very smooth surfaces, like } \\
\text { glass } \\
\text { - mainly opaque. Some white } \\
\text { samples were } \\
\text { subtranslucent. } \\
\text { - color varies from white to } \\
\text { yellow, red, brown and } \\
\text { orange } \\
\text { - some samples contained } \\
\text { fossil plant remains (likely } \\
\text { reeds) } \\
\text { - vugs with a drusy interior } \\
\text { are common } \\
\text { - fractures conchoidally } \\
\text { - many samples were more } \\
\text { brittle than the jasper or } \\
\text { sandstone }\end{array}$ \\
\hline 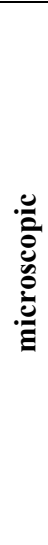 & & $\begin{array}{l}\text { - large quantity of fine-grained quartz } \\
\text { crystals associated with Fe oxides } \\
\text { and hydroxides (i.e. goethite and } \\
\text { hematite) } \\
\text { - in some samples the quartz grains are } \\
\text { evenly spread out and relatively } \\
\text { equigranular. In other samples } \\
\text { larger grains appear to be clustered } \\
\text { in globules surrounded by Fe-rich } \\
\text { mineral phases and smaller quartz } \\
\text { grains } \\
\text { - clusters of manganese oxides } \\
\text { - many samples are fractured with the } \\
\text { fractures being infilled with } \\
\text { microfibrous quartz. }\end{array}$ & $\begin{array}{l}\text { - the main component is } \\
\text { small grains of quartz } \\
\text { - also contains some clay } \\
\text { minerals and a hematitic } \\
\text { pigment } \\
\text { - in between the quartz } \\
\text { grains, there is a fine- } \\
\text { grained quartzitic cement } \\
\text { - some samples show } \\
\text { clusters of manganese } \\
\text { oxides }\end{array}$ & $\begin{array}{l}\text { - primarily composed of } \\
\text { microcrystalline and } \\
\text { microfibrous quartz (i.e. } \\
\text { chalcedony), and some CT- } \\
\text { opal } \\
\text { - Fe is a common component } \\
\text { - fossil plant remains are } \\
\quad \text { visible in some samples }\end{array}$ \\
\hline
\end{tabular}

The material is brecciated. Microscopic thin sections show a quartzitic sandstone which consists of small grains of quartz, some clay minerals and a hematitic pigment.

The sinter material from Brad is associated with Neogene age andesite. The parent rock formation is pyroclastic quartitic andesite with amphiboles and pyroxene of Neogene age (Miocene, Sarmatian) (Bleahu et al., 1964; Bordea and Borcoş, 1972; Ghergari et al., 1999). North-east of Brad (Hunedoara County) there is a large occurrence of this material (Ghiţulescu et al., 1968; Ghergari and Ionescu, 1999). The sinter has various colors, from white to yellow, red, brown or orange. It is opaque, glassy, with a very fine-grained surface. Mineralogically, the sinter is composed of microcrystalline quartz, fibrous microquartz i.e. chalcedony, and some CT-opal (Ghergari and Ionescu, 1999; Ghergari et al., 1999).

The samples from Poieni and Brad were used as controls to see if there would be a clear different between them and the other samples.

\section{PGAA}

Together with the whole artifacts, small chips from the geological samples were chemically analyzed by PGAA at the Budapest Neutron Centre (Révay et al., 2008). This analytical method is based on the detection of prompt- and decay $\gamma$-photons, emitted in the (n, $\gamma)$ reaction (Kasztovszky et al., 2008a, b). The elements are identified by the characteristic $\gamma$-energies, while the quantitative data result from the peak intensities. The standardization is based on a prompt $\mathrm{k}_{0}$-library (Molnár et al., 1998). The spectroscopic data libraries were developed at the Budapest Research Reactor (Révay et al., 2001). The composition was determined using the methods described by Révay (2009), the uncertainties of the concentration values were determined according to Révay (2006). From the point of the owner of the objects, it is essential that the radioactive products usually decay within a few days.

The measurements were done at the $1 \cdot 10^{8} \mathrm{~cm}^{-2} \mathrm{~s}^{-1}$ external cold $\left(20^{\circ} \mathrm{K}\right)$ neutron beam of the $10 \mathrm{MW}$ Budapest Research Reactor. The acquisition time varied between 2600 and $54000 \mathrm{~s}$, depending on the sample size. The $\gamma-$ photons from the bulk material were detected by a calibrated HPGe-BGO detector system in Compton suppressed mode (Molnár et al., 2002), and the spectra were collected by $16 \mathrm{k}$ multichannel analyzer. The spectrum fit was done by HYPERMET PC software (Révay et al., 2005).

Major elements of $\mathrm{SiO}_{2}, \mathrm{TiO}_{2}, \mathrm{Al}_{2} \mathrm{O}_{3}, \mathrm{Fe}_{2} \mathrm{O}_{3}, \mathrm{MnO}$, $\mathrm{MgO}, \mathrm{CaO}, \mathrm{Na}_{2} \mathrm{O}, \mathrm{K}_{2} \mathrm{O}$, and LOI $\left(\mathrm{H}_{2} \mathrm{O}\right.$ and $\left.\mathrm{CO}_{2}\right)$ were identified in most of the samples. The following trace elements were also measured: $\mathrm{B}, \mathrm{S}, \mathrm{Cl}, \mathrm{Sc}, \mathrm{V}, \mathrm{Cr}, \mathrm{Ni}, \mathrm{Nd}$, $\mathrm{Sm}$, and Gd. The components, which appeared to be above the quantification level in most of the samples, were $\mathrm{SiO}_{2}$, $\mathrm{Fe}_{2} \mathrm{O}_{3}, \mathrm{MnO}, \mathrm{K}_{2} \mathrm{O}$, LOI $\left(\mathrm{H}_{2} \mathrm{O}\right), \mathrm{B}, \mathrm{Cl}$, and $\mathrm{Gd}$. The following components were measurable in only a few samples: $\mathrm{Al}_{2} \mathrm{O}_{3}, \mathrm{C}, \mathrm{S}, \mathrm{Sc}, \mathrm{V}, \mathrm{Cr}, \mathrm{Ni}$, and $\mathrm{Nd}$. 


\section{Statistical interpretation}

SPSS software (Field, 2009) was used to perform statistical interpretation of the PGAA data. Although a larger number of samples would have produced more reliable results, the number of analyses was limited by the available beam time. The dataset was interpreted by factorial analysis and principal component (PC) analysis.

\section{RESULTS}

\section{PGAA}

The results of the PGAA are shown in Table 2 . Concentrations of major components are given in $\mathrm{wt} \%$ of oxides, while trace elements are in ppm of elemental forms. Due to the very high silica and occasionally high iron content, in most of the samples, it was not possible to quantify all the major components.

As expected, $\mathrm{SiO}_{2}$ is the prevailing major component, ranging from $\sim 82$ to $\sim 98 \mathrm{wt} . \%$ in geological samples (plus one sample having only $\sim 60 \mathrm{wt} . \%$, possibly an outlier). The artifacts appeared to be more homogeneous and contain a narrow range of $\mathrm{SiO}_{2}$, between 93 and $98 \mathrm{wt} \%$. Among geological samples, those from the western part of the Metaliferi Mts. tend to be more homogeneous and silica rich (>82 wt.\%). The amount of $\mathrm{Fe}$ also shows large variety, ranging from 0.06 to 29.30 wt. $\%$ (Table 2). In the petrographic thin sections there was also a large variation in iron content in different sample. Other elements show insignificant quantities and are related probably to some dispersed phases, such as clay minerals, oxides and hydroxides. Carbon was identified in samples WM-5 Gurasada and EMT-7 Ampoița but was not included into the bulk composition and most likely is related to the presence of some carbonates. Both of these samples had higher levels of $\mathrm{CaO}$ as well. This may relate to calcite that was observed in some petrographic thin sections.

\section{Linear discriminant analysis}

For the statistical interpretation of the PGAA data, only the oxides/elements which were above the quantification limit in most of the samples were used i.e. $\mathrm{SiO}_{2}, \mathrm{Fe}_{2} \mathrm{O}_{3} \mathrm{t}, \mathrm{MnO}$, $\mathrm{K}_{2} \mathrm{O}$, LOI $\left(\mathrm{H}_{2} \mathrm{O}\right), \mathrm{B}, \mathrm{Cl}$ and $\mathrm{Gd}$. Linear discriminant analysis (LDA) was previously used to identify sources (Crandell, 2009) i.e. to determine to which of the geological groups the artifacts are related. The interpretation of our data resulted in outlining the most probable source and second most probable source area, respectively (Tables 3 and 4).

LDA was conducted twice. In the first interpretation, the source of the sandstone and sinter samples were considered unknown (as is the case with artifacts). In the second interpretation, the sandstone and sinter samples were indicated (thus comprising very low populated groups of one or two samples each). In both cases, all of the geological samples had their geographic source correctly predicted with a probability of 0.984 to 1.000 , or $98 \%$ to $100 \%$ probability. In the first interpretation (Table 3), the sandstone and sinter samples were also given predictions of their source (i.e., one of the two jasper groups). The probability of these predictions was also calculated as 1.000 . As the control samples are not from either group, and in fact not even the same material, the probability of the predictions should actually be very low. In the second interpretation (Table 4), one of the artifacts was predicted to be sandstone with a probability of 0.926 . Since this artifact is not sandstone (and neither are any of the others), this probability is far too high.

\section{Principal component analysis}

Based on principal component analysis, the first three principal components have Eigenvalues greater than 1 (PC-3 being only slightly higher) and cumulatively account for $76.6 \%$ of variance. SPSS computed principal components by Varimax rotation with Kaiser normalization. The results of PCA are shown in Table 5. Table 6 shows the rotated factor loadings, which are the correlations between each variable (oxides and elements) and the factor. In other words, it shows which variables make up each of the first 3 PCs and indicates which variables have more discriminating value. The values of the first two principal components (PC-1 vs. PC-2) were plotted on a two dimensional graph to show the relation of the samples (geological and archaeological) to each other (Fig. 4). The first two PCs appear to be sufficient to cluster the samples into the pre-defined material groups. Although as seen in the diagram, there is not a complete separation of the groups but instead an area of overlap. This makes it difficult to use only PC analysis to distinguish between sources or to determine provenance of an artifacts. There is even greater overlap of the four specific source groups. Of note, the geological samples from the Trascău Mts. seem to cluster more tightly than the rest of the EMT samples (i.e., those from the Eastern Metaliferi Mts.) even though both should be from the same group. This may be due to more variation among jasper at that end of the formation.

\section{Ternary diagram}

A better separation of the material groups (jasper sources) can be seen on a ternary diagram of the first three variables of Principal Component 1 (i.e., $\mathrm{Cl}, \mathrm{SiO}_{2}$, and $\mathrm{H}_{2} \mathrm{O}$ ) (Fig. 5). Most of the artifacts are located among the Eastern Metaliferi and Trascău jaspers. Among the geological samples, there is a slight separation of the west Metaliferi jaspers and the east Metaliferi jaspers.

\section{DISCUSSION}

All of the artifacts analyzed received a prediction of their source but the incorrect predictions given for the control samples (particularly considering their high probability) casts doubt upon the reliability of the predictions given for the artifacts. The predictions may be correct but they must be considered with caution. In both cases, the statistical interpretations of the data were mostly correct in predicting the geological/geographical origins of the geological samples, when used as controls (see also Crandell, 2009).

The high probability of the predictions may be caused by several factors. For example, the number of geological samples may be too small; there may be a grade of change from one geological zone to another; the artifacts may have been chemically altered to a large extend due to weathering processes; or the artifacts may in fact be from another source distinct from those in the geological dataset. As noted, the sample populations in this study were very small, 


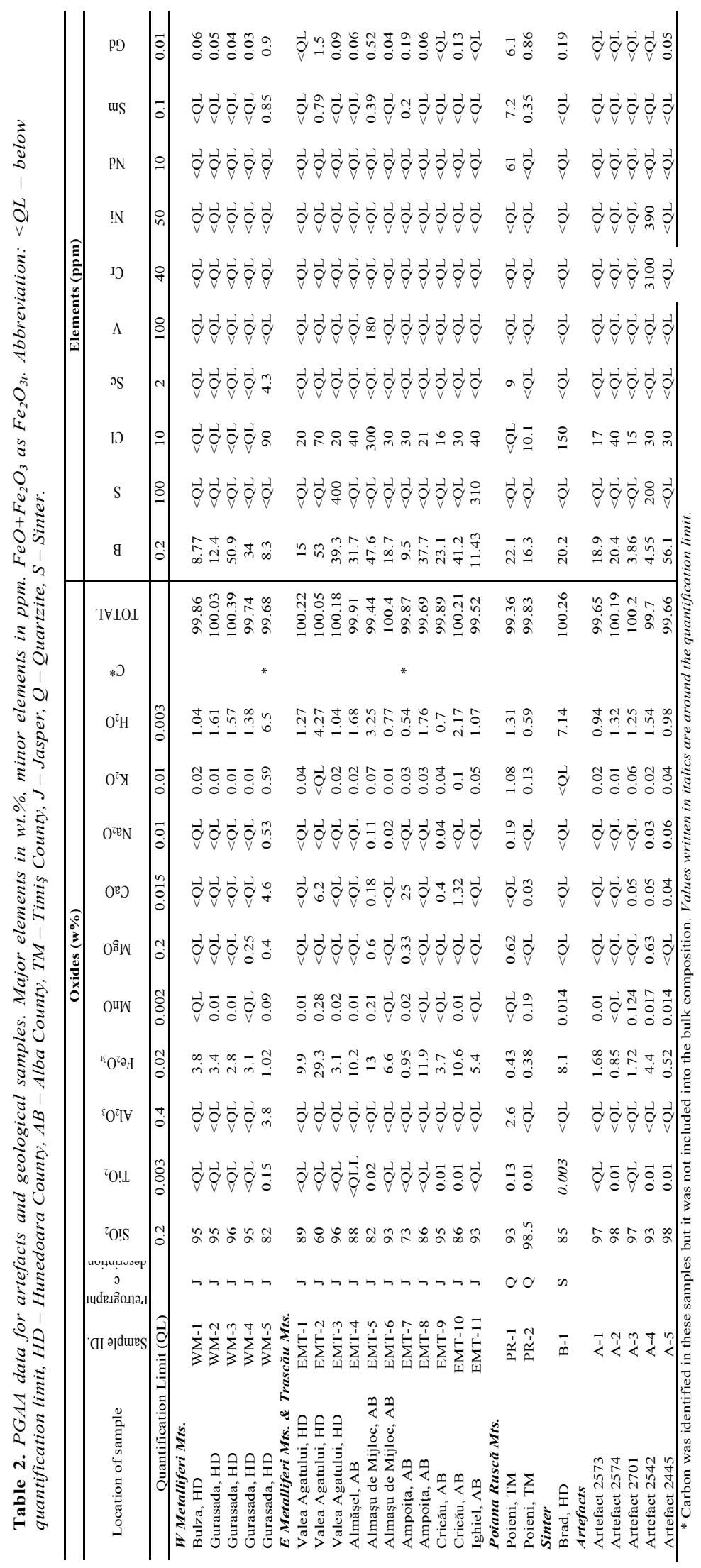


Table 3. Results of LDA for specific sources (first interpretation). Abbreviation: WM - West Metaliferi Mts., EMT - East Metaliferi and Trascău Mts., PR - Poiana Rusca Mts., B - Brad.

\begin{tabular}{|c|c|c|c|c|}
\hline $\begin{array}{c}\text { Artifact } \\
\text { no. }\end{array}$ & $\begin{array}{c}\mathbf{1}^{\text {st }} \\
\text { predicted } \\
\text { Group } \\
\end{array}$ & Probability & $\begin{array}{c}2^{\text {nd }} \\
\text { predicted } \\
\text { Group } \\
\end{array}$ & Probability \\
\hline WM-1 & WM & 0.992 & EMT & 0.008 \\
\hline WM-2 & WM & 1.000 & EMT & 0.000 \\
\hline WM-3 & WM & 1.000 & EMT & 0.000 \\
\hline WM-4 & WM & 1.000 & EMT & 0.000 \\
\hline WM-5 & WM & 1.000 & EMT & 0.000 \\
\hline EMT-1 & EMT & 1.000 & WM & 0.000 \\
\hline EMT-2 & EMT & 1.000 & WM & 0.000 \\
\hline EMT-3 & EMT & 0.995 & WM & 0.005 \\
\hline EMT-4 & EMT & 1.000 & WM & 0.000 \\
\hline EMT-5 & EMT & 1.000 & WM & 0.000 \\
\hline EMT-6 & EMT & 1.000 & WM & 0.000 \\
\hline EMT-7 & EMT & 1.000 & Alm & 0.000 \\
\hline EMT-8 & EMT & 1.000 & WM & 0.000 \\
\hline EMT-9 & EMT & 1.000 & WM & 0.000 \\
\hline EMT-10 & EMT & 1.000 & WM & 0.000 \\
\hline EMT-11 & EMT & 1.000 & WM & 0.000 \\
\hline PR-1 & EMT & 1.000 & WM & 0.000 \\
\hline PR-2 & EMT & 1.000 & WM & 0.000 \\
\hline B-1 & WM & 1.000 & EMT & 0.000 \\
\hline $\begin{array}{c}\text { Artifact } \\
2573\end{array}$ & WM & 0.992 & EMT & 0.008 \\
\hline $\begin{array}{l}\text { Artifact } \\
2574\end{array}$ & WM & 1.000 & EMT & 0.000 \\
\hline $\begin{array}{l}\text { Artifact } \\
2701\end{array}$ & WM & 1.000 & EMT & 0.000 \\
\hline $\begin{array}{l}\text { Artifact } \\
2542\end{array}$ & WM & 1.000 & EMT & 0.000 \\
\hline $\begin{array}{l}\text { Artifact } \\
2445\end{array}$ & EMT & 1.000 & WM & 0.000 \\
\hline
\end{tabular}

*Misclassified cases

** Low probabilities (less than 0.8 )
Table 4. Results of LDA for specific sources (second interpretation). Abbreviation: WM-West Metaliferi Mts., EMT-East Metaliferi and Trascău Mts., PR - Poiana Ruscă Mts., B - Brad.

\begin{tabular}{|c|c|c|c|c|}
\hline $\begin{array}{c}\text { Artifact } \\
\text { no. }\end{array}$ & $\begin{array}{c}1^{\text {st }} \\
\text { predicted } \\
\text { Group } \\
\end{array}$ & Probability & $\begin{array}{c}2^{\text {nd }} \\
\text { predicted } \\
\text { Group } \\
\end{array}$ & Probability \\
\hline WM-1 & WM & 0.997 & EMT & 0.003 \\
\hline WM-2 & WM & 1.000 & EMT & 0.000 \\
\hline WM-3 & WM & 1.000 & EMT & 0.000 \\
\hline WM-4 & WM & 1.000 & EMT & 0.000 \\
\hline WM-5 & WM & 1.000 & EMT & 0.000 \\
\hline EMT-1 & EMT & 1.000 & WM & 0.000 \\
\hline EMT-2 & EMT & 1.000 & WM & 0.000 \\
\hline EMT-3 & EMT & 0.984 & WM & 0.016 \\
\hline EMT-4 & EMT & 1.000 & WM & 0.000 \\
\hline EMT-5 & EMT & 1.000 & WM & 0.000 \\
\hline EMT-6 & EMT & 1.000 & WM & 0.000 \\
\hline EMT-7 & EMT & 1.000 & Alm & 0.000 \\
\hline EMT-8 & EMT & 1.000 & WM & 0.000 \\
\hline EMT-9 & EMT & 1.000 & WM & 0.000 \\
\hline EMT-10 & EMT & 1.000 & WM & 0.000 \\
\hline EMT-11 & EMT & 1.000 & WM & 0.000 \\
\hline PR-1 & PR & 1.000 & Alm & 0.000 \\
\hline PR-2 & PR & 1.000 & Alm & 0.000 \\
\hline B-1 & B & 1.000 & WM & 0.000 \\
\hline $\begin{array}{c}\text { Artifact } \\
2573\end{array}$ & WM & 0.950 & EMT & 0.050 \\
\hline $\begin{array}{c}\text { Artifact } \\
2574\end{array}$ & WM & 1.000 & EMT & 0.000 \\
\hline $\begin{array}{c}\text { Artifact } \\
2701\end{array}$ & PR & 0.926 & EMT & 0.074 \\
\hline $\begin{array}{c}\text { Artifact } \\
2542\end{array}$ & WM & 1.000 & EMT & 0.000 \\
\hline $\begin{array}{c}\text { Artifact } \\
2445\end{array}$ & EMT & 1.000 & WM & 0.000 \\
\hline
\end{tabular}

Table 5. Total variance explained.

\begin{tabular}{cccc}
\hline \multirow{2}{*}{ Component } & \multicolumn{3}{c}{ Initial Eigenvalues } \\
& Total & \% of variance & Cumulative \% \\
\hline 1 & 3.126 & 39.076 & 39.076 \\
2 & 1.970 & 24.626 & 63.701 \\
3 & 1.031 & 12.884 & 76.585 \\
4 & 0.732 & 9.155 & 85.740 \\
5 & 0.610 & 7.621 & 93.361 \\
6 & 0.294 & 3.677 & 97.039 \\
7 & 0.188 & 2.349 & 99.387 \\
8 & 0.049 & 0.613 & 100.000 \\
\hline
\end{tabular}

Table 6. Rotated component matrix.

\begin{tabular}{cccc}
\hline \multicolumn{3}{c}{ Component } \\
& $\mathbf{1}$ & $\mathbf{2}$ & $\mathbf{3}$ \\
\hline $\mathrm{H}_{2} \mathrm{O}$ & 0.869 & & \\
$\mathrm{Cl}$ & 0.803 & \\
$\mathrm{SiO}_{2}$ & -0.665 & \\
$\mathrm{MnO}$ & 0.577 & \\
$\mathrm{Gd}$ & & 0.976 & \\
$\mathrm{~K}_{2} \mathrm{O}$ & & 0.964 & \\
$\mathrm{~B}$ & & & 0.833 \\
$\mathrm{Fe}_{2} \mathrm{O}_{3} \mathrm{t}$ & & & 0.752 \\
\hline
\end{tabular}


thus it is possible that a larger sample set would increase the reliability of the predictions.

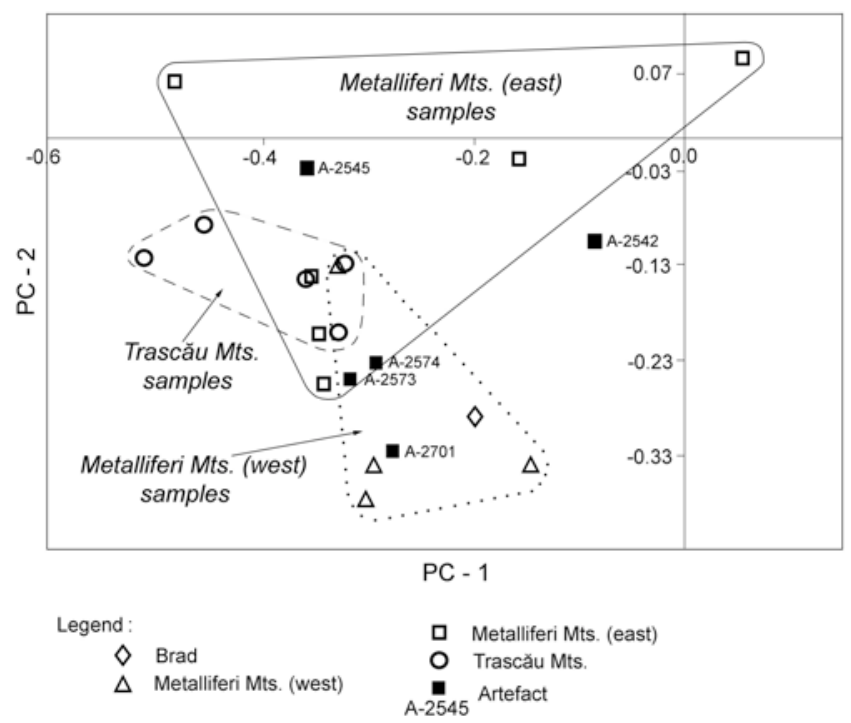

Fig. 4. Principal component analysis plot of the PGAA data.

The interpretation of the PGAA data suggests that for the artifacts no. 2573, 2574, 2701, and 2542 the most likely source is the Western Metaliferi Mts. and that artifact no. 2445 most likely comes from eastern part of the Metaliferi Mts. or Trascău Mts. But as mentioned previously, the accuracy of this prediction is questionable. The use of a ternary plot of oxides and elements also supports the prediction that the material of the artifacts came from the Western Metaliferi sources.

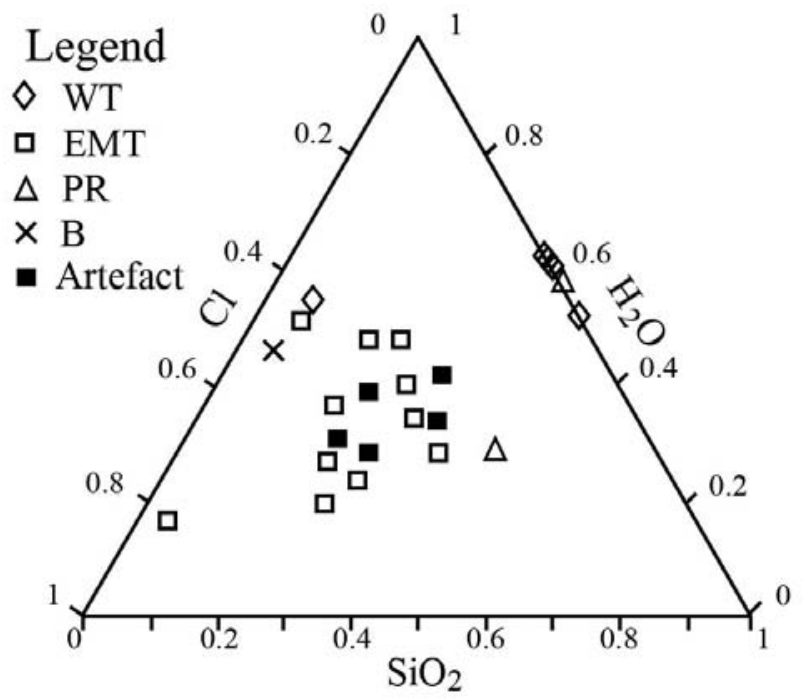

Fig. 5. Plot of $P G A A$ data in the $\mathrm{Cl}-\mathrm{SiO}_{2}-\mathrm{H}_{2} \mathrm{O}$ ternary diagram. Abbreviation: WM - West Metaliferi Mts., EMT - East Metaliferi and Trascău Mts., PR - Poiana Ruscă Mts., B - Brad.

\section{CONCLUSIONS}

PGAA shows limitations in measuring very low levels of trace elements in jasper. Additionally the number of trace elements that can be measured by PGAA is restricted. Due to these, the method might produce inconclusive results for discriminating between similar jaspers originating from different sources. Nevertheless, interpretations of the data may be used for general assessments of provenance. A larger number of analyses may give more accurate results.

A higher number of geological samples may increase the accuracy of the predictions as well as make the indicated probability more realistic. Although PGAA may be able to aid in the identification of lithic sources, with only a small number of geological samples for comparison, results should be verified by other means such as optical microscopy.

Acknowledgments. Thanks are due to archaeologists Cristian Florescu and Iuliu Paul from the Institute of Systemic Archaeology (Alba Iulia, Romania) for providing the artifacts used for this study and for determining their cultural and chronological origins, as well as to Zsolt Kasztovszky of the Budapest Neutron Centre (Hungary) for his part in carrying out the PGAA analyses. The PGAA measurements were performed with the technical support of the Budapest Neutron Centre (Hungary) and were financially supported by the European Commission through the $6^{\text {th }}$ Framework Programme FP6 contract no. RII3-CT2003-505925. NAP VENEUS05 Contract No. OMFB $00184 / 2006$ supported the technical background of the PGAA experiments. This study was also financially supported by funds of the PNII-ID 2241/2008 project (CNCS-UEFISCDI, Romanian Ministry of Education and Research).

\section{R E F E R E N C E S}

Bleahu, M., Savu, H. \& Borcoş, M. 1964, Geological Map of Romania, 1:200,000; Brad Sheet, Romanian Geological Institute, Bucharest.

Borcoş, M., Berbeleac, I., Bordea, S., Bordea, J., Mantea, G. \& Boştinescu, S. 1981, Geological Map of Romania, 1:50000; Zlatna Sheet, Romanian Institute of Geology and Geophysics, Bucharest.

Bordea, S., Borcoş, M. 1972, Geological Map of Romania, 1:50000; Brad Sheet, Romanian Geological Institute, Bucharest.

Comşa, E. 1971, "Banat"-type flint. Apulum, 9: 15-19. [Romanian: Silexul de tip «bănățean»].

Comşa, E. 1976, Les matières premières en usage chez les hommes Néolithiques de l'actuel territoire Rouman. Acta Archaeologica Carpathica (Krakow), 16: 239249.

Crandell, O.N. 2008, Regarding the procurement of lithic materials at the Neolithic Site at Limba (Alba County, Romania): sources of local and imported materials. In Geoarchaeology and Archaeomineralogy (Kostov, R.I., Gaydarska, B., \& Gurova, M., Eds.), Proceedings of the International Conference, 29-30 October 2008 Sofia, p. 36-45.

Crandell, O.N. 2009, A mathematical-statistical algorithm for interpreting geochemical data; explanations and preliminary results with XRF and INAA data. Arheometrie in Romania (Cluj Napoca), 3: 171-178 (In Romanian).

Field, A. 2009, Discovering statistics using SPSS. SAGE Publications Ltd., $821 \mathrm{p}$.

Florescu, C. 2007, A history lesson. Pottery manufacturing 8000 years ago. Ed. Aeternitas, Alba Iulia, 146 p. 
Gandrabura, E.I. 1981, Mineralogical, petrographic geochemical study of the mesozoic eruptives of the Trascău Mountains. Anuarul Institutului de Geologie şi Geofizică, 58: 5-121 (In Romanian).

Gherasi, N., Mureşan, M., Muresan, G., Kräutner, H., Kräutner, F., Lupu, M., Marinescu, F., Savu, H. \& Drăgulescu, A.A. 1965, Geological Map of Romania, 1:200,000; Deva Sheet, Romanian Geological Institute, Bucharest.

Ghergari, L., Ionescu, C. 1999, Genetic considerations on jasper in the Brad area (Apuseni Mts., Romania). Romanian Journal of Mineralogy, Suppl. 1, p. 79.

Ghergari, L., Ionescu, C. \& Püspoki, Z. 1999, Jasper occurrences in the Brad Area, Apuseni Mountains (Romania). Gems and Gemology, 35 (3): 139-140.

Ghițulescu, T., Verdeş, G. \& Chința, R. 1968, Silicolite ores of the Neogene Basin of Brad (Hunedoara county). Studii şi cercetări de Geologie-Geofizică-Geografie, Seria, Geologie (Bucharest), 13 (1): 67-76 (In Romanian).

Ghiurcă, V. 1997a, Archaeological gemology and current gemological resources from the northern part of the Trascău Mountains. Acta Musei Napocensis, Preistorie-Istorie Veche-Arheologie, 34 (1): 829-835 (In Romanian).

Ghiurcă, V. 1997b, Geology of gemological resources of Alba County. Studia UBB Geologia, 42 (2): 25-32 (In Romanian).

Graetsch, H. 1994, Structural characteristics of opaline and microcrystalline silica minerals. Reviews in Mineralogy, 29: 209-232.

Hoard, R.J., Bozell, J.R., Holen, S.R., Glascock, M.D., Neff, H. \& Elam, J.M. 1993, Source determination of White River Group silicates from two archaeological sites in the Great Plains. American Antiquity, 58 (4): 698-710. http://dx.doi.org/10.2307/282203

Ilie, M.D. 1952, Geological research between the Cricău Valley and the Ampoița Valley (Alba). Dări de Seamă ale Şedinţelor, 33: 26-30 (In Romanian).

Julig, P.J. 1995, The sourcing of chert artifacts by INAA: Some examples from the Great Lakes Region. Journal of World Anthropology, 1 (2), Accessed: 09 October 2012, http://wings.buffalo.edu/research/anthrogis/JWA/V1N2/j ulig-pap.html

Julig, P.J., Long, D.F.G., McFarland, V. \& Schroeder, B. 2007, Sourcing of archaeological flints from the Middle to Upper Paleolithic Transition, at Jerf Al-Ajla Cave, Syria. In Chert availability and prehistoric exploitation in the Near East (Delage, C., Ed.), John and Erica Hedges, BAR International Series 1615, Oxford, p. 130-151.

Kasztovszky, Z., Biró, K.T., Markó, A. \& Dobosi, V.T. 2008a, Cold neutron prompt gamma activation analysis A non-destructive method for characterization of high silica content chipped stone tools and raw materials. Archaeometry, 50 (1): 12-29.

Kasztovszky, Z., Biró, K.T., Markó, A. \& Dobosi, V.T. 2008 b, Prompt gamma activation analysis for nondestructive characterization of chipped stone tools and raw materials. Journal of Radioanalytical and Nuclear Chemistry, 278 (2): 293-298.

http://dx.doi.org/10.1007/s10967-008-9505-4

Luedtke, B.E. 1978, Chert sources and trace-element analysis. American Antiquity, 43 (3): 413-423. http://dx.doi.org/10.2307/279398

Studia UBB Geologia, 2012, 57 (1), 3-11
Luedtke, B.E. 1979, The identification of sources of chert artifacts. American Antiquity, 44 (4): 744-757. http://dx.doi.org/10.2307/279116

Luedtke, B.E., Meyers, J.T. 1984, Trace element variation in Burlington Chert: A case study. In: Prehistoric chert exploitations: studies from the midcontinent (Butler, B., May, E., Eds.), Center for Archaeological Investigations, Southern Illinois University, Carbondale, p. 287298.

Lupu, M., Borcoş, M., Dimian, M., Lupu, D. \& Dimitrescu, R. 1966, Geological Map of Romania, 1:200.000; Turda Sheet, Romanian Geological Institute, Bucharest.

Lupu, M., Marinescu, F., Roşu, E., Nicolae, I., Mureşan, M. \& Popescu, A. 1991, Geological Map of Romania, 1:50.000; Lapugiu Costei Sheet, Romanian Institute of Geology and Geophysics, Bucharest.

Lupu, M., Pelty, S., Boştinescu, S., Roşu, E., Kräutner, H.G., Horvath, A., Mureşan, M., Mureşan, G., Bandrabur, T., Popescu, A. \& Nicolae, I. 1986, Geological Map of Romania, 1:50.000; Gurasada Sheet, Romanian Institute of Geology and Geophysics, Bucharest.

Molnár, G., Révay, Z., Paul, R. \& Lindstrom, R. 1998, Prompt-gamma activation analysis using the $\mathrm{k} 0$ approach. Journal of Radioanalytical and Nuclear Chemistry, 234 (1): 21-26. http://dx.doi.org/10.1007/BF02389741

Molnár, G.L., Révay, Z. \& Belgya, T. 2002, Wide energy range efficiency calibration method for Ge detectors. Nuclear instruments and methods in physics research, Section A: Accelerators, spectrometers, detectors and associated equipment, 489 (1-3): 140-159. http://dx.doi.org/10.1016/S0168-9002(02)00902-6

Mureşan, M., Orăşanu, T. 1972, Geological Map of Romania, 1:50.000; Luncani Sheet, Romanian Geological Institute, Bucharest.

Nicolae, I., Saccani, E. 2003, Petrology and geochemistry of the Late Jurassic calc-alkaline series associated to Middle Jurassic ophiolites in the South Apuseni Mountains (Romania). Schweizerische Mineralogische und Petrographische Mitteilungen, 83 (1): 81-96.

Révay, Z. 2006, Calculation of uncertainties in prompt gamma activation analysis. Nuclear instruments and methods in physics research, Section A: Accelerators, spectrometers, detectors and associated equipment, 564 (2): 688-697. http://dx.doi.org/10.1016/j.nima.2006.04.016

Révay, Z. 2009, Determining elemental composition using prompt $\gamma$ activation analysis, Analytical Chemistry, 81 (16): 6851-6859. http://dx.doi.org/10.1021/ac9011705

Révay, Z., Belgya, T. \& Molnár, G.L. 2005, Application of Hypermet-PC in PGAA. Journal of Radioanalytical and Nuclear Chemistry, 265 (2): 261-265. http://dx.doi.org/10.1007/s10967-005-0818-2

Révay, Z., Belgya, T., Szentmiklósi, L. \& Kis, Z. 2008, Recent developments of prompt gamma activation analysis at Budapest. Journal of Radioanalytical and Nuclear Chemistry, 278 (3): 643-646. http://dx.doi.org/10.1007/s10967-008-1401-4

Révay, Z., Molnár, G., Belgya, T., Kasztovszky, Z. \& Firestone, R. 2001, A new gamma-ray spectrum catalog and library for PGAA. Journal of Radioanalytical and Nuclear Chemistry, 248 (2): 395-399. http://dx.doi.org/10.1023/A:1010684210532 
Rossman, G.R. 1994, Colored varieties of the silica minerals. Reviews in Mineralogy, 29: 433-468.

Russo-Săndulescu, D., Berza, T., Bratosin, I. \& Ianc, R. 1976, Contribution to the petrological study of several alpine magmatites from the north of the Trascău Mountains. Dări de Seamă ale Şedinţelor Institutului de Geologie, 62: 165-194 (In Romanian).
Savu, H. 1990, Remarks on the Mesozoic magmatic activity in the Trascău Mountains (Mureş Zone). Revue Roumaine de Géologie, Géophysique et Géographie, Série de Géologie, 34: 13-24.

Vass, D., Balogh, K. 1987, The periods of main and late Alpine molasses. Zeitschrift der Geologische Wissenschaften (Berlin), 17: 849-858. 